\title{
Identification of two distinct mesenchymal stromal cell populations in human malignant glioma
}

\author{
Andreas Svensson ${ }^{1,2} \cdot$ Tania Ramos-Moreno ${ }^{1,2} \cdot$ Sofia Eberstål $^{1,2} \cdot$ Stefan Scheding $^{1,3}$. \\ Johan Bengzon ${ }^{1,2}$
}

Received: 9 February 2016 / Accepted: 9 October 2016 / Published online: 18 October 2016

(C) The Author(s) 2016. This article is published with open access at Springerlink.com

\begin{abstract}
Gene profiling has revealed that malignant gliomas can be divided into four distinct molecular subtypes, where tumors with a mesenchymal gene expression are correlated with short survival. The present investigation was undertaken to clarify whether human malignant gliomas contain endogenous mesenchymal stromal cells (MSC), fulfilling consensus criteria defined by The International Society for Cellular Therapy, recruited from the host. We found that MSC-like cells can be isolated from primary human malignant gliomas. Two distinct MSC-like cell populations, differing in their expression of the CD90 surface marker, were discovered after cell sorting. RNA sequencing revealed further genetic differences between these two cell populations and MSC-like cells lacking CD90 produced higher amounts of VEGF and $\mathrm{PGE}_{2}$ compared to cells with the true MSC phenotype, implying that the CD90- ${ }^{-}$MSC-like cells most probably are more active in tumor vascularization and immunosuppression than their $\mathrm{CD}^{+} 0^{+}$counterpart. The results highlight the $\mathrm{CD}^{-} 0^{-}$subpopulation as an important tumor component, however, its functional effects in glioma remains to be resolved. Using the protocols presented here, it will be possible to isolate, characterize and analyze brain tumor-derived MSC-like
\end{abstract}

Tania Ramos-Moreno

tania.ramos_moreno@med.lu.se

1 Lund Stem Cell Center, BMC B10, Lund University, Klinikgatan 26, 22184 Lund, Sweden

2 Department of Clinical Sciences, Division of Neurosurgery, Lund University, Box 117, 22100 Lund, Sweden

3 Department of Hematology, Skåne University Hospital, Lund, Sweden cells in more detail and to further test their functions in vitro and in in vivo xenograft models of glioma.

Keywords Malignant glioma - Glioblastoma · Mesenchymal stromal cell $\cdot$ CD90

\section{Introduction}

Mesenchymal stromal cells (MSC) are found in a variety of tissues where they constitute a stem cell pool [1]. They can be mobilized to sites of inflammation and angiogenesis, such as wounded tissue and, importantly, various solid cancers [2-4]. No single MSC-specific marker exists for in vivo detection of this cell type and it has been shown that the marker expression of MSCs greatly depends on the tissue in which they reside $[5,6]$. Human MSCs are defined according to in vitro consensus criteria developed by The International Society for Cellular Therapy (ISCT); in culture, MSC should adhere to plastic, they should express CD73, CD90, CD105 but lack expression of CD11b or CD14, CD19 or CD79 $\alpha$, CD34, CD45 and HLA-DR, and they should be able to differentiate into adipocytes, osteoblasts and chondrocytes [7].

MSC constitute a promising vector system for cell mediated gene therapy [8] as they display inherent tumor-tropic migratory capabilities $[9,10]$ are found in several adult tissues [1] and are easy to isolate and expand in vitro [11]. However the use of MSCs as a tumor-tropic cellular vector system in cancer including brain tumor gene therapy also raise several concerns as it is not clarified how the cells affect the tumor and its microenvironment [12]. Consequently the presence and role of endogenous in human brain tumors has now gained attention [13]. Isolation of glioma-associated human MSCs was recently performed. 
Analysis of bulk cultures of primary dissociated tissue from human glioma revealed that glioma-associated MSCs were nontumorigenic stromal cells with phenotypical similarities to bone marrow-derived human MSCs [13]. Genomic sequencing of the glioma-associated MSCs suggested that most MSCs were normal non-transformed cells recruited into the glioma.

The present investigation was undertaken in order to expand on these previous recent findings. For this, a robust protocol for the detection of MSCs using 9 phenotypic markers according to the full ISCT consensus criteria has been developed. Following single cell sorting, we here report the findings of two distinct populations of gliomaderived MSC-like cells that differ in their CD90 expression, their gene expression pattern and their production of proangiogenic VEGF and immune-suppressive $\mathrm{PGE}_{2}$.

\section{Materials and methods}

\section{Tumor samples}

Fourteen primary brain tumor samples were obtained from the neurosurgery department at Skåne University Hospital in Lund, Sweden. Ethical permit H15 642/2008. The tissue was washed in phosphate buffered saline (PBS, Life Technologies, Carlsbad, CA, USA), placed in a Petri dish with StemMACS MSC Expansion Media (Miltenyi Biotec, Bergisch Gladbach, Germany) and minced with a scalpel. Afterwards, cells were washed in PBS and then incubated in Accutase (Sigma-Aldrich, Stockholm, Sweden) at $37^{\circ} \mathrm{C}$ for $20 \mathrm{~min}$. They were rotated every $5 \mathrm{~min}$ to prevent sedimentation. Finally, cells were passed 2-3 times through an $18 \mathrm{G}$ needle before being filtered through a $100 \mu \mathrm{m}$ nylon mesh. The single cell suspension was put in cell culture flasks with MSC Expansion Media.

\section{Cell culturing}

Tumor-derived cells were grown adherently in MSC Expansion Media supplemented with Antibiotic-Antimycotic solution (AAS, Sigma-Aldrich) in cell culturing flasks at $37^{\circ} \mathrm{C}$ and $5 \% \mathrm{CO}_{2}$. Half of the medium was changed $1-3$ times per week. Cells at $70-100 \%$ confluency were passaged using Accutase.

\section{Flow cytometry}

Culture-derived cells at passage 2-4 were stained with the following monoclonal antibodies; Brilliant Violet 421CD73 (AD2), Alexa Fluor 700-CD90 (5E10, both from Nordic BioSite, Täby, Sweden), PE-CD105 (266), PE-Cy5HLA-ABC (G46-2.6), FITC-CD14 (M5E2), FITC-CD19
(HIB19), FITC-CD34 (581), FITC-CD45 (HI30) and FITC-HLA-DR (G46-6, all from BD Biosciences) and isotype matched controls for $30 \mathrm{~min}$ at $4{ }^{\circ} \mathrm{C}$. TO-PRO-1 (Life Technologies) was used as viability marker and cells were analyzed and sorted on a FACSAria III cell sorter (BD Biosciences, Heidelberg, Germany).

\section{Cell sorting}

Culture-derived cells analyzed on the FACSAria III cell sorter were simultaneously sorted based on surface marker expression. Two populations were sorted from each tumor, one expressing the defined MSC phenotype and one expressing the defined MSC phenotype except CD90. Cells were sorted at passage 2-4 and immediately put back in culture.

\section{"In vitro" differentiation}

Sorted tumor-derived stromal cells at passage 8-11 were used for in vitro differentiation assays. Bone marrowderived (BM) MSCs from healthy donors were used as positive control and the experiments were performed as described elsewhere [14].

For adipocyte differentiation, cells were cultured in StemMACS AdipoDiff Media (Miltenyi Biotec) for 14 days. They were fixed with $4 \%$ formaldehyde solution (APL, Stockholm, Sweden) for $60 \mathrm{~min}$ at and then incubated in $60 \%$ isopropanol (VWR International, Stockholm, Sweden) for $5 \mathrm{~min}$ before being stained with $0.18 \%$ Oil Red $\mathrm{O}$ (Sigma-Aldrich) for $5 \mathrm{~min}$, all at room temperature (RT).

For osteoblast differentiation, cells were cultured in osteoblast induction medium for 21 days. They were incubated in ice-cold $70 \%$ ethanol for $1 \mathrm{~h}$ at $4{ }^{\circ} \mathrm{C}$ before being stained with $40 \mathrm{mM}$ Alizarin Red solution (Sigma-Aldrich) for 10 min at RT.

For chondrocyte differentiation, cell pellets were grown in chondrogenesis induction medium for 28 days. They were fixed in Stefanini's fixative [15] and then incubated in 20\% sucrose solution (Merck KGaA, Darmstadt, Germany), both at $4{ }^{\circ} \mathrm{C}$ overnight. The pellets were frozen in Tissue-Tek O.C.T. Compound (Sakura Finetek Sweden AB, Göteborg, Sweden). $5 \mu \mathrm{m}$ thick cryosections were permeabilized and blocked with PBS supplemented with $0.3 \%$ Triton X-100, $0.1 \%$ sodium azide, $0.1 \%$ fish skin gelatin (all from SigmaAldrich) and 10\% normal donkey serum (Jackson ImmunoResearch Europe Ltd., Suffolk, United Kingdom) for $45 \mathrm{~min}$ at RT. They were stained with polyclonal goat antihuman aggrecan antibody ( $5 \mu \mathrm{g} / \mathrm{ml}, \mathrm{R} \& \mathrm{D}$ Systems) at $4{ }^{\circ} \mathrm{C}$ overnight and then Alexa Fluor 594 donkey anti-goat $\operatorname{IgG}$ $(5 \mu \mathrm{g} / \mathrm{ml}$, Life Technologies) for $60 \mathrm{~min}$ at RT. Nuclei were visualized by incubation with Hoechst $33342(8.1 \mu \mathrm{M}$, Life Technologies) for $15 \mathrm{~min}$ at RT. 
Stained adipocytes and osteoblasts were analyzed with a Nikon Diaphot 300 and a Nikon D70 (both from Nikon, Yurakucho, Tokyo, Japan). Chondrocyte pellets were analyzed with an Olympus BX61 and an Olympus DP72 (both from Olympus, Shinjuku, Tokyo, Japan).

\section{RNA-sequencing extraction and gene analysis measurements}

Total RNA from GBM-47 (passage number 2); GBM-48 (passage number 2); GBM-47-derived MSC-like CD90cells (passage number 8); GBM-48-derived MSC-like $\mathrm{CD}^{-}{ }^{-}$cells (passage number 5); GBM-47-derived MSClike $\mathrm{CD}^{+} 0^{+}$(passage number 10); GBM-48-derived MSClike $\mathrm{CD}^{+}{ }^{+}$(passage number 6 ); U87 primary GBM cell line (passage number 30) and human bone-marrow derived MSC (hBM-MSC, passage number 1, from a 61 years old healthy male donor) was isolated by using RNAesay (Qiagen) with DNase treatment. RNA was extracted according to manufacturer instructions and their concentration was determined spectrophotometrically by Nanodrop-ND 1000 spectophotometer (Nanodrop). RNA quality was analyzed using a Bioanalyzer (Agilent) and samples with a RNA integrity greater than seven were further analyzed. Subsequent RNA amplification and analysis were largely performed as previously reported in $[16,17]$ except that libraries were prepared using TruSeq Stranded mRNA Kit for NeoPrep from Illumina.

\section{ELISA}

Sorted tumor-derived stromal cells at passage 10-13 were analyzed for VEGF and $\mathrm{PGE}_{2}$ production using ELISA. $1 \times 10^{5}$ cells/well were plated in a 24 well plate and grown in $1 \mathrm{ml} \mathrm{MSC} \mathrm{Expansion} \mathrm{Media} \mathrm{for} 24 \mathrm{~h}$. Supernatants were collected, centrifuged and stored at $-80^{\circ} \mathrm{C}$ prior to analysis. VEGF levels were determined using the Human VEGF DuoSet kit (R\&D Systems). PGE 2 levels were determined using the Prostaglandin $E_{2}$ EIA kit (Cayman Chemical Company, Larodan Fine Chemicals, Malmö, Sweden). Experiments were performed in duplicate on three separate occasions.

\section{Statistical analysis}

The RNA sequencing data processing was performed using the analysis pipe line method described in SCAN-B article [16]. Thus, after the first filtering processes, only the mRNAs showing differential expression between different groups are taken for further analysis. To compare the mRNA expression profile between the 2 GBM-derived MSC groups, CD90 ${ }^{-}$and $\mathrm{CD}^{+}$cells, simple $t$ test was used and a $\mathrm{p}$ value $<0.01$ was considered significant. The VEGF and $\mathrm{PGE}_{2}$ production analysis was performed using
Two-way ANOVA, where $\mathrm{p}<0.05$ was considered statistically significant. Linear regression analysis was performed correlating the survival time of patients to \% total MSC in bulk culture or $\mathrm{CD}^{+} 0^{+}$cells in bulk culture or $\mathrm{CD}^{-}{ }^{-}$cells in bulk culture in all possible combinatorial forms. A p value lower than 0.05 was considered to be significant.

\section{Results}

\section{Cells with MSC marker expression profile are present in human primary brain tumor cultures}

Tumor specimens from 14 different glioma patients grown adherently in vitro and displayed a fibroblastic morphology consistent with MSCs (Fig. 1a-c). All 14 tumor samples were grown as bulk cultures. In all of these cultures, large numbers of spindle shaped cells with a morphology fully compatible with MSCs were observed attached to the plastic surface of the culture flask. Cells in bulk cultures were easily expandable, however, since we aimed for sorting at the lowest passage number possible, bulk cultures were never passaged more than a few times. We then assessed, by flow cytometry, whether cells fulfilling the consensus marker expression profile for MSCs are present in human gliomas.

At passage 2-4, all tumors contained a small subpopulation of cells expressing the full MSC phenotype, as analysed by flow cytometry (Fig. 1d-f). Numerous cells displaying the full MSC consensus marker panel except for CD90 were detected. The fraction of MSC-like cells relative to the total number of cells in culture varied within a wide range (Table 1; Fig. 1d-f). Notable was that in the majority of the tumors, the number of cells displaying the $\mathrm{CD}^{-} 0^{-}$phenotype was larger than the $\mathrm{CD} 90^{+}$population. Routine pathological diagnosis revealed that the tumor with the noticeably highest amount of MSC-like cells was a gliosarcoma. Another interesting finding was that the low-grade astrocytoma (AC45) contained notably fewer MSC-like cells than most of the high-grade GBMs, however no correlation was observed between patient survival and the \% of MSC-like cells in the tumor (data not shown).

\section{MSC phenotype-expressing cells isolated from human brain tumors can differentiate into osteoblasts and, to some extent, adipocytes and chondrocytes}

Next, we determined if the cells expressing MSC markers had the capacity to differentiate into adipocytes, osteoblasts and chondrocytes. Cells were sorted using FACS according to the consensus criteria defined by ISCT. Two populations from each tumor were isolated, one expressing the defined MSC phenotype and one expressing the defined phenotype except CD90. Sorted cells from only two different tumors 
Fig. 1 In vitro images of adherently grown a BM-MSCs, b glioma-derived MSC-like CD90 ${ }^{-}$cells and $\mathbf{c}$ gliomaderived MSC-like CD90 ${ }^{+}$cells. Scale bar $500 \mu \mathrm{m}$. d BM-MSCs and culture-derived tumor cells from e GBM-47 and f GBM-48 were analyzed and sorted for MSC markers with flow cytometry. Cells were stained for markers defining MSCs (CD73, CD90, CD105 and HLA class I). Doublets, dead cells and cells expressing lineage negative markers (CD14, CD19, CD34, CD45 and HLA-DR) were used as a cocktail in Lin TO-PRO-1 and have already been excluded

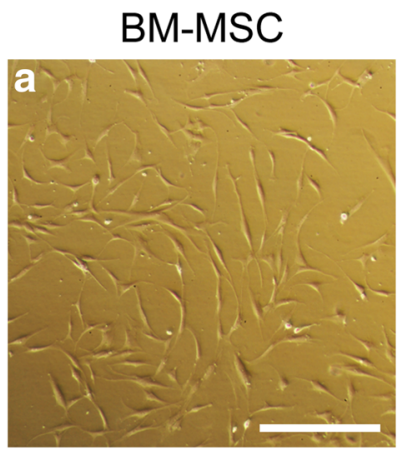

GBM-47 (CD90-) GBM-47 (CD90+)
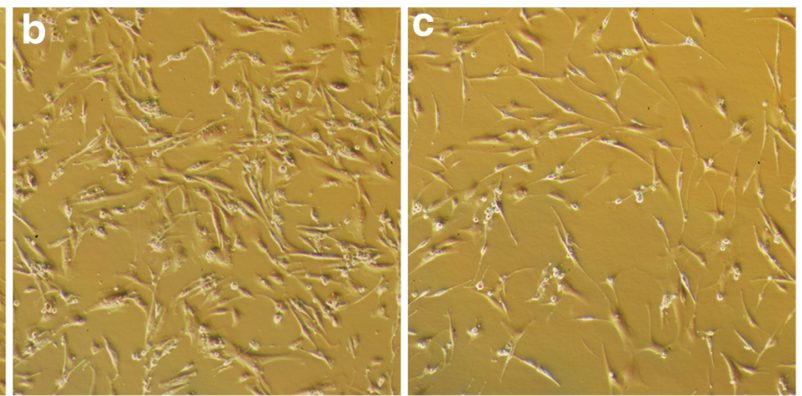

BM-MSC

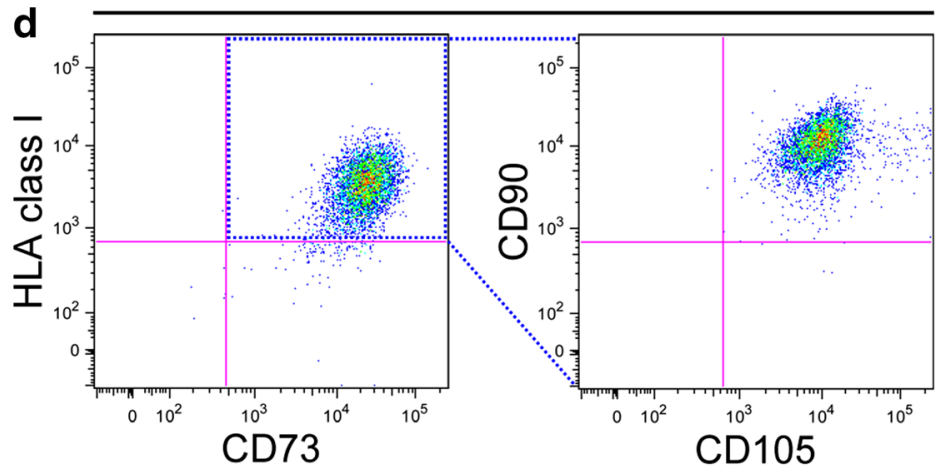

GBM-47

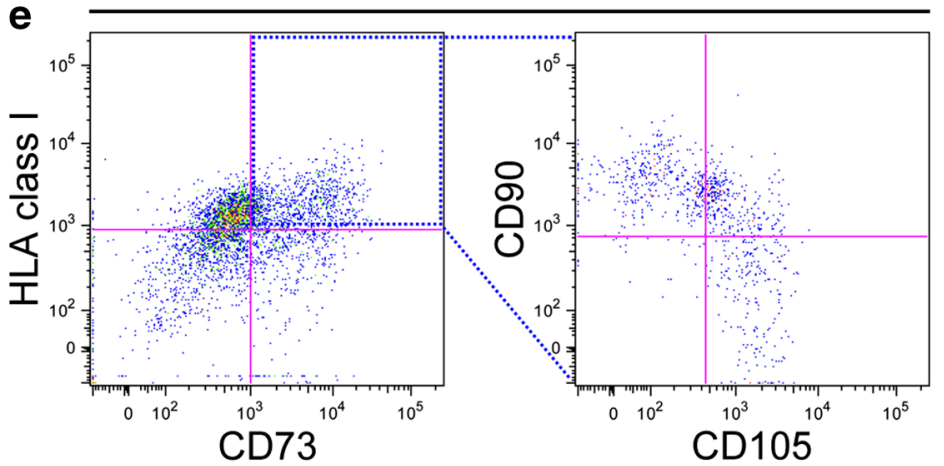

GBM-48

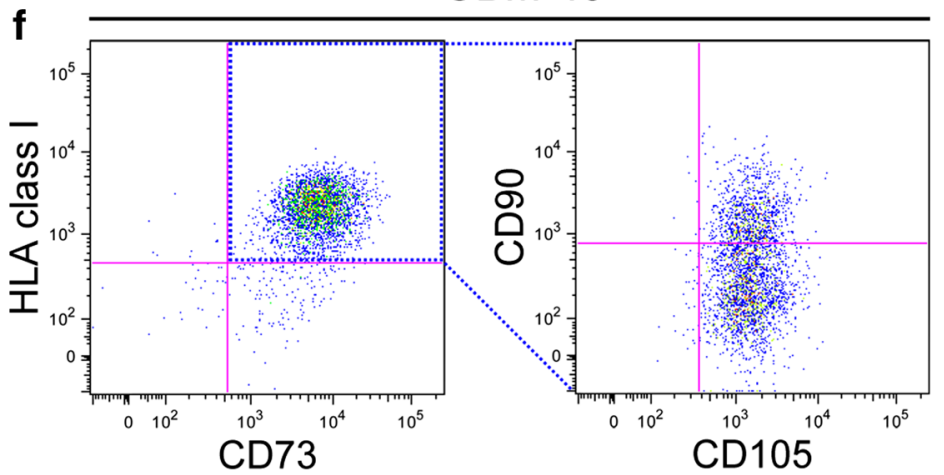

were able to proliferate in vitro and were thus analyzed further. Before sorting, cells had been passaged for 2-4 times and after sorting these cells were again passaged for a maximal total passage number of 14 .
Possible adipocyte differentiation was only detected in the $\mathrm{CD} 90^{-}$population of GBM-47 (Fig. 2a). In the CD $90^{+}$ population, and in the sorted cells from GBM-48, the cells were clearly changed by the adipogenic differentiation 
Table 1 Fourteen human brain tumors and BM-MSCs analyzed for MSC marker expression using flow cytometry

\begin{tabular}{|c|c|c|c|c|c|c|c|c|}
\hline Sample & Sex & $\begin{array}{l}\text { Age } \\
\text { (years)* }\end{array}$ & Diagnosis & Grade & $\begin{array}{l}\text { Passage at } \\
\text { analysis }\end{array}$ & $\begin{array}{l}\text { MSC** to total } \\
\text { cell ratio in } \\
\text { culture }(\%)\end{array}$ & $\begin{array}{l}\mathrm{CD}^{-} 0^{-} \mathrm{MSC} \\
\text { population in } \\
\text { culture }(\%)\end{array}$ & $\begin{array}{l}\text { Survival } \\
\text { (months) }\end{array}$ \\
\hline BM-MSC & - & - & - & - & 5 & 97.1 & - & - \\
\hline AC-45 & $\mathrm{m}$ & 31 & Astrocytoma & II & 4 & 0.539 & 3.73 & 24 \\
\hline ODG-44 & $\mathrm{f}$ & 49 & Oligodendro-glioma & III & 2 & 3.62 & 35.3 & $* * *$ \\
\hline GBM-40 & $\mathrm{m}$ & 75 & GBM & IV & 4 & 13.6 & 85.4 & 9 \\
\hline GBM-43 & $\mathrm{m}$ & 78 & GBM & IV & 4 & 1.43 & 21.3 & 9 \\
\hline GBM-46 & $\mathrm{m}$ & 56 & GBM & IV & 3 & 0.417 & 4.03 & 3 \\
\hline GBM-47 & $\mathrm{m}$ & 58 & GBM & IV & 2 & 7.19 & 5.58 & 16 \\
\hline GBM-48 & $\mathrm{m}$ & 71 & GBM & IV & 2 & 29.6 & 63.5 & 1 \\
\hline GBM-49 & $\mathrm{f}$ & 69 & GBM & IV & 3 & 1.33 & 13.7 & 10 \\
\hline GBM-51 & $\mathrm{m}$ & 60 & GBM & IV & 2 & 1.68 & 0.525 & 27 \\
\hline GBM-52 & $\mathrm{m}$ & 76 & GBM & IV & 4 & 4.13 & 6.33 & 1 \\
\hline GBM-53 & $\mathrm{m}$ & 62 & Gliosarcoma & IV & 2 & 34.3 & 48.7 & 17 \\
\hline GBM-54 & $\mathrm{m}$ & 69 & GBM & IV & 2 & 11.0 & 27.4 & 11 \\
\hline GBM-55 & f & 62 & GBM & IV & 4 & 1.94 & 0.203 & 8 \\
\hline GBM-56 & $\mathrm{m}$ & 45 & GBM & IV & 4 & 0.0183 & 2.63 & $* * *$ \\
\hline
\end{tabular}

*Age at the time of surgery

**Positive for CD73, CD90, CD105, HLA class I; negative for CD14, CD19, CD34, CD45, HLA-DR

$* * *$ Alive

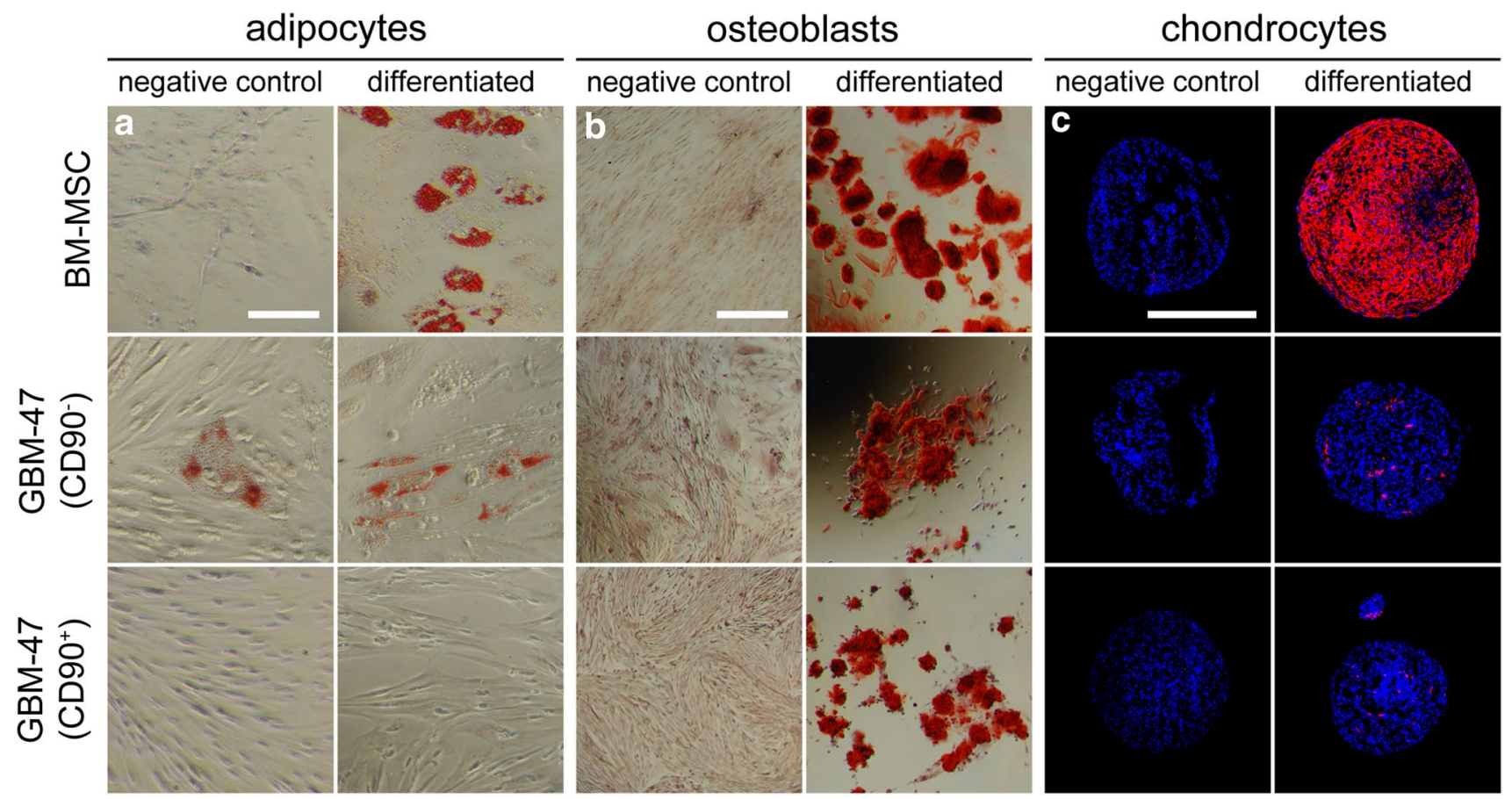

Fig. 2 Sorted tumor-derived stromal cells were differentiated into a adipocytes, $\mathbf{b}$ osteoblasts and $\mathbf{c}$ chondrocytes. Light microscope images reveal lipid vacuoles in adipocytes and calcium deposits in osteoblasts.

stimulation but no clear lipid vacuole staining was visible. Further on, all sorted cells, even the ones lacking CD90, had the capacity to differentiate into osteoblasts (Fig. 2b). Finally, both the $\mathrm{CD} 90^{-}$and $\mathrm{CD} 90^{+}$population from
Epifluorescent images show aggrecan staining (red) on chondrocytes. Nuclei are blue. Scale bar $100 \mu \mathrm{m}$ in a and $500 \mu \mathrm{m}$ in $\mathbf{b}$ and $\mathbf{c}$

GBM-47 formed chondrocytes (Fig. 2c), as assessed by aggrecan immunoreactivity, whereas the corresponding populations from GBM-48 only showed weak aggrecan expression (data not shown). 
We conclude that cells displaying a complete MSC phenotype can be present in human brain tumor specimens. MSC-like cells lacking CD90 isolated from primary human brain tumors could differentiate into osteoblasts, adipocytes and chondrocytes, whereas the corresponding cells expressing CD90 only formed osteoblasts and chondrocytes.

\section{Differential mRNA expression in $\mathrm{CD}^{+}{ }^{+}$and $\mathrm{CD90}^{-}$ MSC-like populations}

Differentially expressed gene (DEG) analysis of the transcriptional profile associated with the different cell types here analyzed (GBM, GBM-derived MSC, U87 and hBM-MSC) revealed that there is a different mRNA expression profile between the 2 sorted MSC-like cells, CD90 ${ }^{+}$and $\mathrm{CD} 90^{-}$ (Fig. 3a). A $t$ test was subsequently performed to identify differentially expressed genes between $\mathrm{CD} 90^{-}$and $\mathrm{CD} 90^{+}$ cell types, this resulted in total, 211 genes (135 up regulated and 76 down regulated in $\mathrm{CD}^{+} 0^{+}$cell lines). Differentially expressed genes were next subjected to functional annotation analysis using Metacore web-based software (https://portal. genego.com/) and results show that, amongst the up regulated genes in the $\mathrm{CD} 90^{+}$cell lines, $50 \%$ were enriched for the glutathione metabolism; $25 \%$ were enriched for the cytoskeleton remodeling and $8.3 \%$ for cell adhesion. Amongst the down-regulated genes, $46.7 \%$ were involved in apoptosis and survival; $33.3 \%$ were involved in the immune response and $13.3 \%$ in cell adhesion (Fig. 3b-d). Interestingly, and although cell surface expression of CD90 clearly separates two distinct populations of glioma-derived MSC-like cells, the CD90 mRNA expression profile was not significantly different between these two cell populations and thus, was not taken into account for the different analysis (Fig. 3).

\section{The CD90- ${ }^{-}$MSC-like population produces more VEGF and $\mathrm{PGE}_{2}$ compared to its $\mathrm{CD}^{+}{ }^{+}$counterpart}

The two cell populations that were expandable following cell sorting were analyzed for VEGF and $\mathrm{PGE}_{2}$ production. The results show that the $\mathrm{CD} 90^{-}$cells from two GBMs secreted significantly higher levels of VEGF compared to the $\mathrm{CD} 90^{+}$cells from the same tumors (mean 166 and $58.6 \mathrm{pg} / \mathrm{ml}$, respectively, $\mathrm{p}<0.01$; Fig. $4 \mathrm{a}$ ).

The $\mathrm{CD} 90^{-}$population from GBM-47 also produced considerably more $\mathrm{PGE}_{2}$ compared to the $\mathrm{CD} 90^{+}$population from the same tumor (mean 9830 and $234 \mathrm{pg} / \mathrm{ml}$, respectively, $\mathrm{p}<0.01)$. Similar, the $\mathrm{PGE}_{2}$ production of the $\mathrm{CD} 90^{-}$population from GBM-48 produced significantly more $\mathrm{PGE}_{2}$ compared to the $\mathrm{CD} 90^{+}$population from the same tumor (mean 213 and $55.5 \mathrm{pg} / \mathrm{ml}$, respectively, p $<0.05$; Fig. 4b).

\section{Discussion}

Malignant gliomas with a mesenchymal gene expression profile are associated with an invasive growth pattern and short survival and recurring tumors often display a mesenchymal phenotype $[18,19]$. In this study, we analyzed 14 primary human malignant gliomas and conclude that all of them harbor cells expressing surface markers defined by ISCT [7].

By employing a stricter flow cytometric analysis, adhering to the ISCT criteria, and by, for the first time for this particular purpose, sorting cells, we expand on previous reports of MSC-like cells in malignant glioma [13]. We found that malignant gliomas harbor two distinct MSC-like cell populations, differing in their CD90 expression. Although a different tri-mesenchymal differentiation capacity was noticed between $\mathrm{CD} 90^{+}$and $\mathrm{CD} 90^{-}$populations, as indicated by adipocyte differentiation only in cells lacking CD90, this data is preliminary and further experiments, optimizing the expansion of MSC clones from a larger number of tumor samples, is warranted in order to confirm if the absence of adipocyte differentiation is a distinctive feature of $\mathrm{CD} 90^{+}$ cell population.

In most tumor samples, the $\mathrm{CD} 90^{-}$population was larger than the $\mathrm{CD} 90^{+}$population. Both populations were expandable and retained their proliferative capacity in vitro. Unfortunately, these cell populations were difficult to detach from the plastic surface during the first passages and we could only perform complete studies in cells derived from 2 patients. The number of MSC-like cells compared to the total number of cells (MSC to total cell number in culture in Table 1) following 2-4 passages in vitro showed a very wide variation. Yet, the present study was not designed in order to quantify the ratio of MSC-like cells within glioma stroma. Interestingly though, the tumor with the highest proportion of MSC-like cells was a gliosarcoma, a GBM subtype with a clear mesenchymal component [14].

To confirm that the two MSC-like cell populations CD90 ${ }^{+}$ and $\mathrm{CD} 90^{-}$constitute two distinct cell populations, we analyzed their gene expression profile. Although we were limited in the number of samples, the mRNA expression profiles clearly support the notion that these are, in fact, two different populations. Intriguingly, although the cell surface expression of CD90 separates these populations, their CD90 mRNA expression profile did not differ, suggesting that cell surface glycoprotein CD90 could be either engulfed from the surface due to a cell reaction to some environmental stimuli, thus becoming undetectable on the surface or, that $\mathrm{CD} 90^{-}$cells react to some stimuli and overexpress CD90 as a response to the stimuli. In vitro angiogenic stimuli, for example, generate hM-MSC lacking CD90 expression [20] whilst 
a
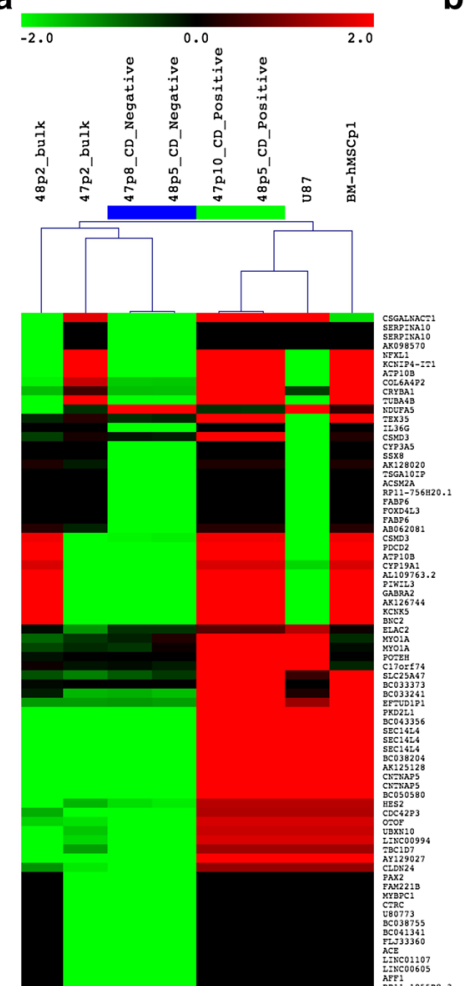

b

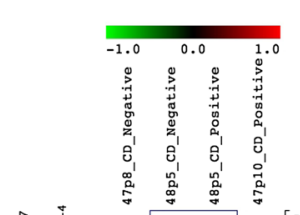

11
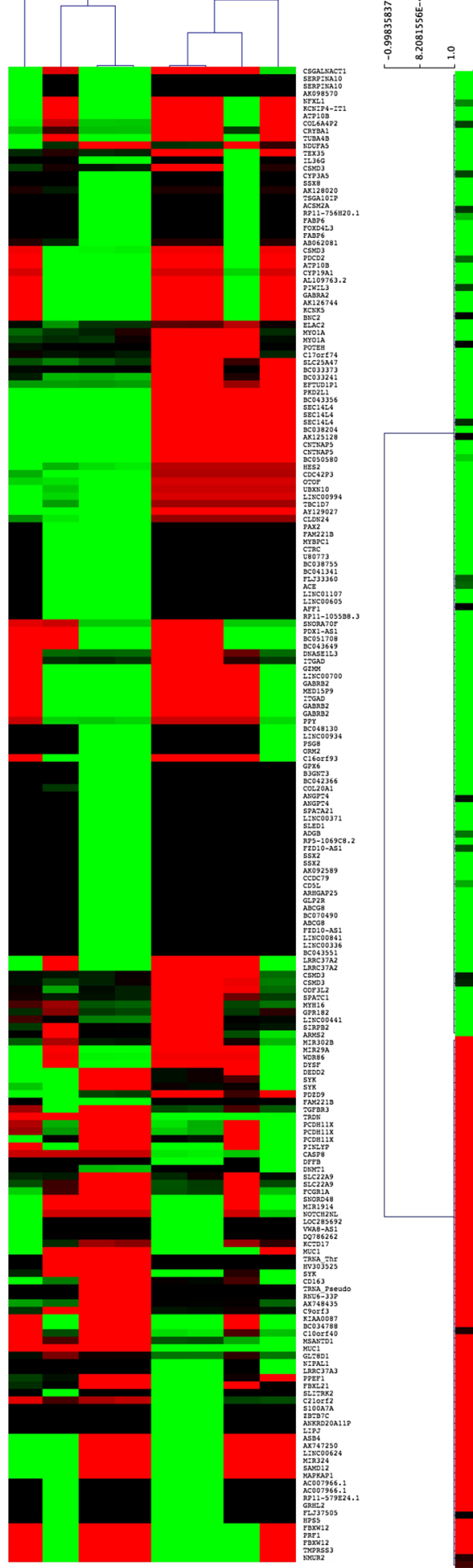

c

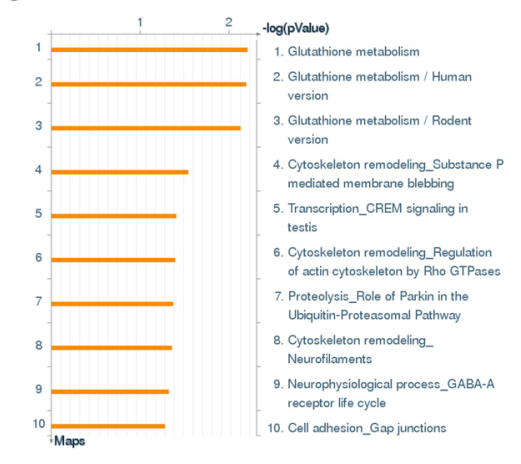

d

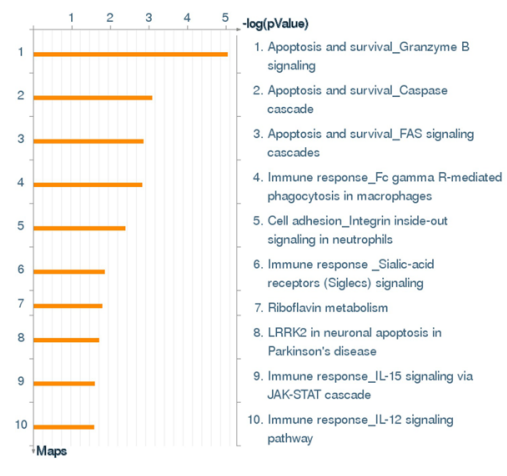


4Fig. 3 a Heatmap of genes differentially expressed in RNA-sequencing analysis performed on GBM-47; GBM-48; GBM-47/48-derived MSC-like CD90- cells; GBM-47/48-derived MSC-like CD90 ${ }^{+}$; U87 primary GBM cell line and bone-marrow derived MSC show gliomaderived MSC-like $\mathrm{CD} 90^{-}$and $\mathrm{CD} 90^{+}$cells gene expression patterns to be different $\left(\mathrm{p}<0.01\right.$, paired Student's $t$ test). CD $90^{+}$cells clustering with U87 and later with hBM-MSC, may possibly reflect a similar pluripotency stage. b Unsupervised hierarchical sample clustering between glioma-derived MSC-like CD90 $0^{-}$and CD90 ${ }^{+}$cells $(\mathrm{p}<0.01$, paired Student's $t$ test). c Significantly up-regulated canonical pathways within the transcriptional profile from the MSC-like CD $90^{+}$cells versus MSC-like CD90 ${ }^{-}$cells. d Significantly down-regulated canonical pathways within the transcriptional profile from the MSC-like $\mathrm{CD}^{+} 0^{+}$cells versus $\mathrm{MSC}-$-like $\mathrm{CD} 90^{-}$cells

overexpression of surface cell markers upon inflammatory stimuli has been already reported for neurotrophic receptors [21]. In addition, mechanical stress has been reported to decrease CD90 cell surface glycoprotein in MSC [22]. Since little mechanical stress was performed during culturing, and the number of passages were low when mRNA expression analysis was performed, this hypothesis is quite unlikely. Alternatively, the CD90 mRNA could suffer any type of posttranslational preventing the receptor from being visible on the surface $[23,24]$. Future experiments for a further deep characterization of $\mathrm{CD} 90^{+}$and $\mathrm{CD} 90^{-}$populations are envisaged.

Likewise, the functional significance of CD90 expression, or lack thereof, on glioma-derived MSC-like cells needs further investigations. Previous studies have suggested that $\mathrm{CD} 90^{+}$pericytes within gliomas promote vascularization and immunosuppression [15]. However, CD90 has also been reported to be a tumor suppressor [25]. The present study might lend some support to the latter, as we found that the MSC-like $\mathrm{CD}^{-} 0^{-}$cells could be producing elevated levels of VEGF compared to the $\mathrm{CD} 90^{+}$cells from the same tumors. If confirmed, this could indicate that the $\mathrm{CD} 90^{-}$population of glioma-derived MSC-like cells might be more actively involved in tumor angiogenesis than the $\mathrm{CD} 90^{+}$subpopulation. In addition to its critical role in tumor angiogenesis, VEGF has been reported to attract MSCs themselves to glioma cells [3]. Furthermore, VEGF has been reported to stimulate MSC proliferation [26], indicating that autocrine mechanisms might function to stimulate MSC recruitment and proliferation within glioma.

The immunosuppressive function of BM-MSCs is well characterized and utilized clinically [27]. Among the key immunoactive factors expressed by MSCs is prostaglandin $\mathrm{E}_{2}\left(\mathrm{PGE}_{2}\right)$ [28], which has been shown to induce immunosuppression within tumors $[15,29]$. Because of technical reasons, we were only able to expand FACS sorted cells from two glioblastoma, which severely restricted their further analysis. However, interestingly, the CD90- $\mathrm{MSC}-$ like cells secreted markedly higher amounts of $\mathrm{PGE}_{2}$ compared to the $\mathrm{CD} 90^{+}$cells. $\mathrm{PGE}_{2}$ is a molecule known to be important for BM-MSC-induced immunosuppression [30], suggesting that glioma-derived MSC-like cells, and the CD90 ${ }^{-}$subpopulation in particular, may actively contribute to the glioma immunosuppression.

\section{a VEGF production in vitro}

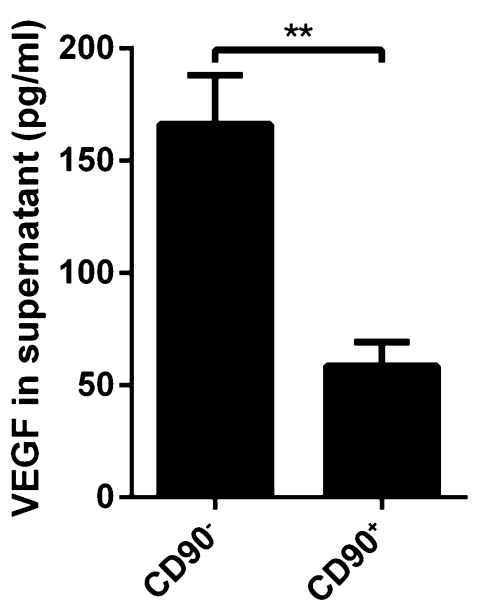

b PGE2 produciton in vitro

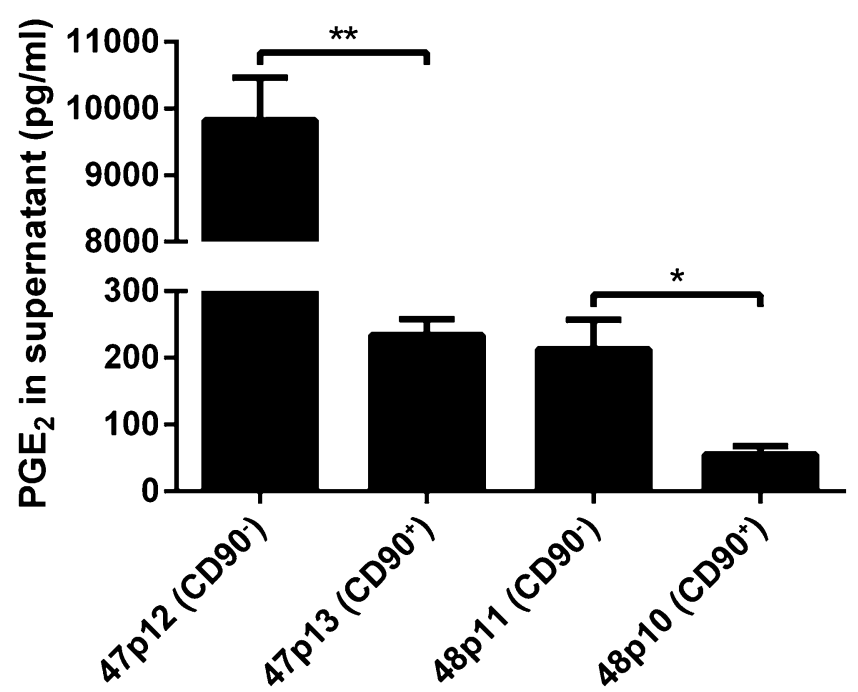

cells were grown in $1 \mathrm{ml}$ MSC Expansion Media for $24 \mathrm{~h}$ and the supernatants were analyzed with ELISA. Each experiment was performed three times in duplicate and VEGF data from both tumors was pooled together 
Even though the source of the glioma-derived MSC-like cells is unknown, the most probable explanation is that the tumor recruits them from normal tissue. Inflammatory factors, such as IL-8 [31], monocyte chemotactic protein-1 [32] and stromal cell-derived factor $1 \alpha$ [33] are known to be expressed in gliomas and have been reported as attractants of MSCs in other cancers [34, 35]. Further on, the extensive angiogenesis within malignant gliomas is believed to play a major part in MSC migration. In addition to VEGF, angiogenic factors such as platelet-derived growth factor$\mathrm{BB}$ [36] and transforming growth factor- $\beta 1$ [3], known to be involved in glioma angiogenesis, have been shown to mediate MSC recruitment [3,34]. Moreover, we have previously shown that drug-mediated angiogenesis inhibition markedly decreased the migration of BM-MSCs transplanted into experimental rat gliomas [10].

In conclusion, we show that two distinct MSC-like cell populations, differing in their expression of the CD90 surface marker expression, can be isolated from primary human malignant gliomas. Further analysis revealed important differences between these two populations with regards to mRNA expression patterns and, present results show that $\mathrm{CD} 90^{-}$cells produced higher amounts of VEGF and $\mathrm{PGE}_{2}$ compared to cells with the true MSC phenotype, implying that $\mathrm{CD} 90^{-}$cells may be more active in tumor vascularization and immunosuppression than their $\mathrm{CD} 90^{+}$counterpart. Taken together, our results highlight the $\mathrm{CD} 90^{-}$MSC-like subpopulation as an important tumor component, however, its functional effects in glioma remains to be resolved. Using the protocols presented here, it will be possible to isolate, characterize and analyze brain tumor-derived MSC-like cells in more detail and to further test their functions in vitro and in in vivo xenograft models of glioma.

Acknowledgments The authors would like to thank Teona Roschupkina and Edward Visse for excellent technical flow cytometry support and Thérése Nilsson, Arshad Jamal, Jan C Brune and Roshanak Ghazanfari for sharing their expertise. We are grateful to Translational and Sequencing Unit at Lund Universityfor their contributions to the RNA sequencing analysis. Likewise, we thank Dr. H. Ahlenius, Dr. I. Artner, MSc Jonas Fritze and MSc Tania Singh for their contribution to the mRNA extraction. This work was supported by a donation from Viveca Jeppsson and grants from the Region Skåne Funds, the ALF grant from the Medical Faculty at Lund University, the Swedish Cancer Society, The Crafoord Foundation and the Gunnar Nilsson Cancer Foundation. The Lund Stem Cell Center was supported by a Center of Excellence grant in Life Sciences from the Swedish Foundation for Strategic Research.

\section{Compliance with ethical standards}

Conflict of interest The authors declare that they have no conflict of interest.

Ethical approval All procedures performed in studies involving human participants were in accordance with the ethical standards of the institutional and/or national research committee and with the 1964 Helsinki declaration and its later amendments or comparable ethical standards.

Open Access This article is distributed under the terms of the Creative Commons Attribution 4.0 International License (http://creativecommons.org/licenses/by/4.0/), which permits unrestricted use, distribution, and reproduction in any medium, provided you give appropriate credit to the original author(s) and the source, provide a link to the Creative Commons license, and indicate if changes were made.

\section{References}

1. Orbay H, Tobita M, Mizuno H (2012) Mesenchymal stem cells isolated from adipose and other tissues: basic biological properties and clinical applications. Stem cells Int 2012:461718. doi: $10.1155 / 2012 / 461718$

2. Spaeth E, Klopp A, Dembinski J, Andreeff M, Marini F (2008) Inflammation and tumor microenvironments: defining the migratory itinerary of mesenchymal stem cells. Gene Ther 15(10):730 738. doi:10.1038/gt.2008.39

3. Birnbaum T, Roider J, Schankin CJ, Padovan CS, Schichor C, Goldbrunner R, Straube A (2007) Malignant gliomas actively recruit bone marrow stromal cells by secreting angiogenic cytokines. J Neurooncol 83(3):241-247. doi:10.1007/ s11060-007-9332-4

4. Droujinine IA, Eckert MA, Zhao W (2013) To grab the stroma by the horns: from biology to cancer therapy with mesenchymal stem cells. Oncotarget 4(5):651-664. doi:10.18632/ oncotarget. 1040

5. Rolandsson S, Andersson Sjoland A, Brune JC, Li H, Kassem M, Mertens F, Westergren A, Eriksson L, Hansson L, Skog I, Bjermer L, Scheding S, Westergren-Thorsson G (2014) Primary mesenchymal stem cells in human transplanted lungs are CD90/CD105 perivascularly located tissue-resident cells. BMJ Open Respir Res 1(1):e000027. doi:10.1136/bmjresp-2014-000027

6. Pinho S, Lacombe J, Hanoun M, Mizoguchi T, Bruns I, Kunisaki Y, Frenette PS (2013) PDGFRalpha and CD51 mark human nestin + sphere-forming mesenchymal stem cells capable of hematopoietic progenitor cell expansion. J Exp Med 210(7):1351-1367. doi:10.1084/jem.20122252

7. Dominici M, Le Blanc K, Mueller I, Slaper-Cortenbach I, Marini F, Krause D, Deans R, Keating A, Prockop D, Horwitz E (2006) Minimal criteria for defining multipotent mesenchymal stromal cells. The International Society for Cellular Therapy position statement. CytoTherapy 8(4):315-317. doi:10.1080/14653240600855905

8. Nakamura K, Ito Y, Kawano Y, Kurozumi K, Kobune M, Tsuda H, Bizen A, Honmou O, Niitsu Y, Hamada H (2004) Antitumor effect of genetically engineered mesenchymal stem cells in a rat glioma model. Gene Ther 11(14):1155-1164. doi:10.1038/ sj.gt.3302276

9. Bexell D, Gunnarsson S, Svensson A, Tormin A, HenriquesOliveira C, Siesjo P, Paul G, Salford LG, Scheding S, Bengzon J (2012) Rat multipotent mesenchymal stromal cells lack longdistance tropism to 3 different rat glioma models. Neurosurgery 70(3):731-739. doi:10.1227/NEU.0b013e318232dedd

10. Bexell D, Gunnarsson S, Tormin A, Darabi A, Gisselsson D, Roybon L, Scheding S, Bengzon J (2009) Bone marrow multipotent mesenchymal stroma cells act as pericyte-like migratory vehicles in experimental gliomas. Mol Ther 17(1):183-190. doi:10.1038/ mt.2008.229 
11. Caplan AI (1991) Mesenchymal stem cells. J Orthop Res 9(5):641-650. doi:10.1002/jor.1100090504

12. Torsvik A, Bjerkvig R (2013) Mesenchymal stem cell signaling in cancer progression. Cancer Treat Rev 39(2):180-188. doi:10.1016/j.ctrv.2012.03.005

13. Hossain A, Gumin J, Gao F, Figueroa J, Shinojima N, Takezaki T, Priebe W, Villarreal D, Kang SG, Joyce C, Sulman E, Wang Q, Marini FC, Andreeff M, Colman H, Lang FF (2015) Mesenchymal stem cells isolated from human gliomas increase proliferation and maintain stemness of glioma stem cells through the IL-6/gp130/STAT3 pathway. Stem Cells 33(8):2400-2415. doi: $10.1002 /$ stem.2053

14. Louis DN, Ohgaki H, Wiestler OD, Cavenee WK, Burger PC, Jouvet A, Scheithauer BW, Kleihues P (2007) The 2007 WHO classification of tumours of the central nervous system. Acta Neuropathol (Berl) 114(2):97-109. doi:10.1007/s00401-007-0243-4

15. Ochs K, Sahm F, Opitz CA, Lanz TV, Oezen I, Couraud PO, von Deimling A, Wick W, Platten M (2013) Immature mesenchymal stem cell-like pericytes as mediators of immunosuppression in human malignant glioma. J Neuroimmunol 265(1-2):106-116. doi:10.1016/j.jneuroim.2013.09.011

16. Saal LH, Vallon-Christersson J, Hakkinen J, Hegardt C, Grabau D, Winter C, Brueffer C, Tang MH, Reutersward C, Schulz R, Karlsson A, Ehinger A, Malina J, Manjer J, Malmberg M, Larsson C, Ryden L, Loman N, Borg A (2015) The Sweden Cancerome Analysis Network-Breast (SCAN-B) Initiative: a large-scale multicenter infrastructure towards implementation of breast cancer genomic analyses in the clinical routine. Genome Med 7(1):20. doi:10.1186/s13073-015-0131-9

17. Hakkinen J, Nordborg N, Mansson O, Vallon-Christersson J (2016) Implementation of an Open Source Software solution for Laboratory Information Management and automated RNAseq data analysis in a large-scale Cancer Genomics initiative using BASE with extension package Reggie. bioRxiv. doi:10.1101/038976

18. Phillips HS, Kharbanda S, Chen R, Forrest WF, Soriano RH, Wu TD, Misra A, Nigro JM, Colman H, Soroceanu L, Williams PM, Modrusan Z, Feuerstein BG, Aldape K (2006) Molecular subclasses of high-grade glioma predict prognosis, delineate a pattern of disease progression, and resemble stages in neurogenesis. Cancer cell 9(3):157-173. doi:10.1016/j.ccr.2006.02.019

19. Verhaak RG, Hoadley KA, Purdom E, Wang V, Qi Y, Wilkerson MD, Miller CR, Ding L, Golub T, Mesirov JP, Alexe G, Lawrence M, O'Kelly M, Tamayo P, Weir BA, Gabriel S, Winckler W, Gupta S, Jakkula L, Feiler HS, Hodgson JG, James CD, Sarkaria JN, Brennan C, Kahn A, Spellman PT, Wilson RK, Speed TP, Gray JW, Meyerson M, Getz G, Perou CM, Hayes DN (2010) Integrated genomic analysis identifies clinically relevant subtypes of glioblastoma characterized by abnormalities in PDGFRA, IDH1, EGFR, and NF1. Cancer Cell 17(1):98-110. doi:10.1016/j. ccr.2009.12.020

20. Campioni D, Lanza F, Moretti S, Ferrari L, Cuneo A (2008) Loss of Thy-1 (CD90) antigen expression on mesenchymal stromal cells from hematologic malignancies is induced by in vitro angiogenic stimuli and is associated with peculiar functional and phenotypic characteristics. CytoTherapy 10(1):69-82. doi:10.1080/14653240701762364

21. Becher B, Antel JP (1996) Comparison of phenotypic and functional properties of immediately ex vivo and cultured human adult microglia. Glia 18(1):1-10

22. Wiesmann A, Buhring HJ, Mentrup C, Wiesmann HP (2006) Decreased CD90 expression in human mesenchymal stem cells by applying mechanical stimulation. Head Face Med 2:8. doi:10.1186/1746-160x-2-8

23. Barker TH, Hagood JS (2009) Getting a grip on Thy-1 signaling. Biochim Biophys Acta 1793(5):921-923. doi:10.1016/j. bbamcr.2008.10.004

24. Gui M, Wiest DL, Li J, Kappes D, Hardy RR, Hayakawa K (1999) Peripheral $\mathrm{CD} 4+\mathrm{T}$ cell maturation recognized by increased expression of Thy-1/CD90 bearing the $6 \mathrm{C} 10$ carbohydrate epitope. J Immunol (Baltimore, Md: 1950) 163(9):4796-4804

25. Abeysinghe HR, Cao Q, Xu J, Pollock S, Veyberman Y, Guckert NL, Keng P, Wang N (2003) THY1 expression is associated with tumor suppression of human ovarian cancer. Cancer Genet Cytogenet 143(2):125-132

26. Pons J, Huang Y, Arakawa-Hoyt J, Washko D, Takagawa J, Ye J, Grossman W, Su H (2008) VEGF improves survival of mesenchymal stem cells in infarcted hearts. Biochem Biophys Res Commun 376(2):419-422. doi:10.1016/j.bbrc.2008.09.003

27. Ghannam S, Bouffi C, Djouad F, Jorgensen C, Noel D (2010) Immunosuppression by mesenchymal stem cells: mechanisms and clinical applications. Stem Cell Res Ther 1(1):2. doi:10.1186/ scrt2

28. Spaggiari GM, Abdelrazik H, Becchetti F, Moretta L (2009) MSCs inhibit monocyte-derived DC maturation and function by selectively interfering with the generation of immature DCs: central role of MSC-derived prostaglandin E2. Blood 113(26):65766583. doi:10.1182/blood-2009-02-203943

29. Djouad F, Plence P, Bony C, Tropel P, Apparailly F, Sany J, Noel D, Jorgensen C (2003) Immunosuppressive effect of mesenchymal stem cells favors tumor growth in allogeneic animals. Blood 102(10):3837-3844. doi:10.1182/blood-2003-04-1193

30. Yanez R, Oviedo A, Aldea M, Bueren JA, Lamana ML (2010) Prostaglandin E2 plays a key role in the immunosuppressive properties of adipose and bone marrow tissue-derived mesenchymal stromal cells. Exp Cell Res 316(19):3109-3123. doi:10.1016/j. yexcr.2010.08.008

31. Kim DS, Kim JH, Lee JK, Choi SJ, Kim JS, Jeun SS, Oh W, Yang YS, Chang JW (2009) Overexpression of CXC chemokine receptors is required for the superior glioma-tracking property of umbilical cord blood-derived mesenchymal stem cells. Stem Cells Dev 18(3):511-519. doi:10.1089/scd.2008.0050

32. Dwyer RM, Potter-Beirne SM, Harrington KA, Lowery AJ, Hennessy E, Murphy JM, Barry FP, O'Brien T, Kerin MJ (2007) Monocyte chemotactic protein-1 secreted by primary breast tumors stimulates migration of mesenchymal stem cells. Clin Cancer Res 13(17):5020-5027. doi:10.1158/1078-0432. ccr-07-0731

33. Menon LG, Picinich S, Koneru R, Gao H, Lin SY, Koneru M, Mayer-Kuckuk P, Glod J, Banerjee D (2007) Differential gene expression associated with migration of mesenchymal stem cells to conditioned medium from tumor cells or bone marrow cells. Stem Cells 25(2):520-528. doi:10.1634/stemcells.2006-0257

34. Bexell D, Svensson A, Bengzon J (2013) Stem cell-based therapy for malignant glioma. Cancer Treat Rev 39(4):358-365. doi:10.1016/j.ctrv.2012.06.006

35. Xu F, Shi J, Yu B, Ni W, Wu X, Gu Z (2010) Chemokines mediate mesenchymal stem cell migration toward gliomas in vitro. Oncol Rep 23(6):1561-1567

36. Nakamizo A, Marini F, Amano T, Khan A, Studeny M, Gumin J, Chen J, Hentschel S, Vecil G, Dembinski J, Andreeff M, Lang FF (2005) Human bone marrow-derived mesenchymal stem cells in the treatment of gliomas. Cancer Res 65(8):3307-3318. doi:10.1158/0008-5472.can-04-1874 